\title{
MOLECULAR DYNAMICS STUDIES OF THE NOROVIRUS-HOST CELL INTERACTION MEDIATED BY H-TYPE 1 ANTIGEN
}

\author{
Abdülkadir KOCAK ${ }^{1 *}$, Muslum YILDIZ ${ }^{2}$ \\ ${ }^{1}$ Department of Chemistry, Gebze Technical University, Kocaeli, TURKEY \\ ${ }^{2}$ Department of Molecular Biology and Genetics, Gebze Technical University, Kocaeli, TURKEY \\ *Corresponding author: ORCID ID: orcid.org/0000-0001-6891-6929, e-mail: kocak@gtu.edu.tr
}

Cite this article as:

Kocak A., Yildiz M. 2019. Molecular Dynamics Studies of the Norovirus-Host Cell Interaction Mediated by H-type 1 Antigen. Trakya Univ J Nat Sci, 20(1): 19-26, DOI: 10.23902/trkjnat.508120

Received: 04 January 2019, Accepted: 27 January 2019, Online First: 30 January 2019, Published: 15 April 2019

\begin{abstract}
Noroviruses are the main cause for acute gastroenteritis disease. They infect the host cell via interaction with HGBA receptors on the cell surface. Virus makes complex with cell surface receptors through its capsid protein VP1 to enter the cell. Although the protein has been successfully crystallized in the presence of some common glycans, the dynamic change in the protein structure when interacting with sugar moieties has yet to be fully elucidated. This is critically important since it leads to understanding the protein's recognition mechanism of HBGAs and develop therapeutic strategies against the gastroenteritis disease. Here, we computationally assessed the dynamic features of wild type VP1 envelope protein to get insights into the interactions that can be important for virus infectivity. We have found that the binding of sugar moiety does not cause noticeable dynamic changes in the binding region. However, interestingly, a drastic change occurs in a distant loop lying at the residue numbers of 395-400, which might be indication of an allosteric effect.
\end{abstract}

Key words: Norovirus, therapeutic antibody, HBGA blockage, molecular dynamics.

Özet: Akut gastroenterit hastalığının önemli nedenlerinden biri norovirüslerdir. Konakçı hücreye, hücre yüzeyindeki çoklu şeker halkalarından oluşan HGBA reseptörleri ile etkileşerek enfekte olurlar. Hücreye girmek için virüse ait kapsid proteini hücre yüzeyi reseptörleri ile kompleksleşir. Her ne kadar protein bazı ortak glikanların varlığında kompleks olarak başarılı bir şekilde kristalize edilmiş olsa da, şeker kısımlarının bağlanmasından kaynaklanan protein yapısındaki dinamik değişim henüz tam olarak aydınlatılamamıștır. Virüs proteinin HBGA'lara bağlanma mekanizmasını anlama ve gastroenterit hastalığına karşı tedavi stratejileri geliştirmesine yardımcı olması nedeniyle bu dinamik değişimi anlamak kritik derecede öneme sahiptir. Bu çalışmada, virüs enfeksiyonu için önemli olabilecek etkileşimler hakkında bilgi edinmek için yabanıl VP1 kapsit proteininin dinamik özelliklerini moleküler dinamik metotlarla hesapladık. Şeker kısmının bağlanmasının, bağlanma bölgesinde gözle görülür dinamik değişikliklere neden olmadığını tespit ettik. Bununla birlikte, ilginç bir şekilde, allosterik bir etkinin göstergesi olabilecek 395-400 numaralı sekansa ait amino asitlerinde ihmal edilemeyecek bir hareketlilik meydana geldiğini gözlemledik.

\section{Introduction}

Gastroenteritis disease is one of the greatest health problems among all infectious diseases. The annual number of people suffering from gastroenteritis worldwide is about 90 million of which the number of deaths is close to 2.5 million (Kotloff et al. 2013, Belliot et al. 2014, Kambhampati et al. 2015). The disease is also the major reason for deaths of 1.8 million children and infants every year (Hoa Tran et al. 2013, Karst et al. 2014, Rocha-Pereira et al. 2014). All populations are susceptible to the causing virus, but elders and children constitute the highest risk group. The infection mostly starts with the ingestion of contaminated food and water and can also be transmitted from person to person during outbreaks. The virus specifically binds to the antigens on the surfaces of red blood cells (erythrocytes) and epithelial cells in the gastrointestinal tract. This binding initiates the infection in these cells. The infectivity of noroviruses is responsible for sporadic gastroenteritis and severe childhood diarrhea. Despite the tremendous scientific efforts, an approved vaccine or an effective antiviral drug has not been developed yet (Tan \& Jiang 2014, Aliabadi et al. 2015).

Noroviruses are classified in six genogroups (GI-GVI) and each group contains several genotypes. The notation used to categorize Norwalk viruses (NV) is given by "GI.1", where "G" stands for genogroup, "I" refers to the $1^{\text {st }}$ genogroup, and " 1 " to genotype 1 . The GI, GII and GIV are principal groups that are responsible for infecting human (Patel et al. 2009, White 2014).

The entrance of Human Noroviruses (HuNoVs) into the cell is initiated by the interaction of the virus protein's domain 1 (VP1) and histo-blood group antigens (HBGAs) (Caddy et al. 2014, Shanker et al. 
2014, de Graaf et al. 2016). This has attracted great scientific attention to develop therapeutics that will block the interaction between VP1 and HBGAs as a cure for virus infection (Lochridge et al. 2005, Garaicoechea et al. 2015, Sapparapu et al. 2016, Tamminen et al. 2016). Thus, several crystal structures that show atomic details of interactions among residues residing in the complex interface are solved (Choi et al. 2008, Kubota et al. 2012, Shanker et al. 2014). Even though the crystal structures have rich information about the interaction, they lack the dynamic features of this interaction. Moreover, so far studies have shown that the interaction is rather weak and binding regions of HBGAs are varied (Ishida 2018).

Here, in order to understand the dynamic properties of residues on the VP1-HGBA complex, we computationally investigated the interaction of an $\mathrm{H}$ type HBGA antigen with VP1. We probed dynamic changes in the VP1 capsid protein that may be visible upon sugar binding. Given the fact that the manipulation of the possible changes can be harnessed for designing new therapeutic agents, our findings can offer opportunity for opening new avenue for treatment of norovirus dependent gastroenteritis disease.

\section{Materials and Methods}

\section{Preparation}

The starting structures of the wild type unliganded (VP1) and liganded (VP1 HBGA complex) were retrieved from the Protein Data Bank (PDB id=2ZL5 and 2ZL6, respectively) (Choi et al. 2008). The protein preparation wizard utility of Maestro (Schrödinger 2015) was used to add the $\mathrm{H}$ atoms, assign bond orders, remove steric clashes and optimize hydrogen-bonding network. The protonation states of acidic and basic amino acids were calculated using Propka 3.1 (Olsson et al. 2011) at $\mathrm{pH}=7$. According to that, negatively charged side chains of Asp and Glu (unprotonated) and positively charged side chains of Arg and Lys (protonated) residues were presumed. The amber99sb-ildn (Lindorff-Larsen $e t$ al. 2010) force field was used for the VP1 protein. The pentasaccharide ligand was first optimized using G09 software at B3LYP/6-311++G(d,p) level by freezing the heavy atoms at the $\mathrm{x}$-ray coordinates. Then, the RESP charges and GAFF parameters were generated using antechamber software (Wang et al. 2004, Wang et al. 2006).

\section{$\underline{\text { Simulation Protocol }}$}

The molecular dynamics simulations were carried out using Gromacs 5.1 software package (Abraham et al. 2015). The system (either containing unliganded or liganded VP1) is placed in the center of a dodecahedron box and solvated in a water box of $\sim 1500 \mathrm{~nm}^{3}$ with the TIP3P model (Toukan \& Rahman 1985) with a cell margin distance of $14 \AA$ for each dimension. Each system consisting of $\sim 145,000$ atoms was neutralized and salted by $0.15 \mathrm{M} \mathrm{NaCl}$. Bonds with hydrogen atoms were restrained to their equilibrium length with LINCS algorithm.

As in our former studies (Kocak et al. 2016, Kocak \& Yildiz 2017), the system was very gently energy minimized within 13 steps, each consisting of 5000 cycles of two subsequent integrators, Steepest Descent and Conjugate Gradient. In the first step, only hydrogen atoms were relaxed while keeping all heavy atoms including water at $4000 \mathrm{~kJ} \cdot \mathrm{mol}^{-1} \cdot \mathrm{nm}^{-2}$. In the second step, the water molecules were relaxed. Next, the side chains were gradually relaxed by reducing the force constants in the order of 4000, 2000, $1000,500,200,50$ and $0 \mathrm{~kJ} \cdot \mathrm{mol}^{-1} \cdot \mathrm{nm}^{-2}$. At the last step of the minimization process, the backbone atoms were also released in the same gradual order.

After minimization, each system was equilibrated within six steps. The first step is a $5 \mathrm{~ns}$ of canonical ensemble. At this step, the system was heated to $310 \mathrm{~K}$ (with time constant of 0.1 ) with a simulated annealing fashion. This temperature was reached in the first $500 \mathrm{ps}$ by linearly heating and kept constant for the next $4.5 \mathrm{~ns}$. The V-rescale thermostat was used as the temperaturecoupling group separately for the protein-ligand complex and surroundings. In the subsequent steps, the system was equilibrated to 1 atm pressure in a stepwise isobaricisothermal ensemble. During this stage, the heavy atoms were smoothly and progressively released. MD simulations were run for $\sim 70 \mathrm{~ns}$ at constant pressure using Langevin Dynamics.

\section{Results and Discussion}

The comparison of molecular dynamics simulations belonging to unliganded (bare VP1) and liganded (complexed VP1) P domain structures reflect the nature of the interaction between the VP1 and HBGA, along with dynamic changes upon binding. Thus, we investigated the RMSD and radius of gyration values of bare and complexed VP1 over time course of MD simulation. These values are lower in complexed VP1 and shows different trend from the complexed structure (Fig. 1), suggesting that the dynamic feature of VP1 varies when the HBGA is attached to it. In order to pin down the specific dynamic variations due to ligand binding, we specifically monitored the distances and fluctuations among residues in the interaction region that were already observed in the crystal structure.

According to the x-ray structures, the residues Gln342, Asp344, His329, Ser377, Asp327, Pro378 and Trp375 are involved in the interaction with H-type 1 pentasaccharide receptor. Among these, the first three residues interact with $\alpha$-fucose and the remaining with $\beta$-Galactose (Fig. 2 ). The last three sugar moieties are not involved in the interaction. Although the sugar moieties have high degrees of freedom due to multiple torsions, the residues in the interacting region maintain in a stable state throughout the MD simulation. The structures from $\mathrm{x}$-ray and MD simulations were superimposed in Fig. 3. The weak binding nature of the receptor to the VP1 protein does not perturb the rigid structures of the residues in this region. 


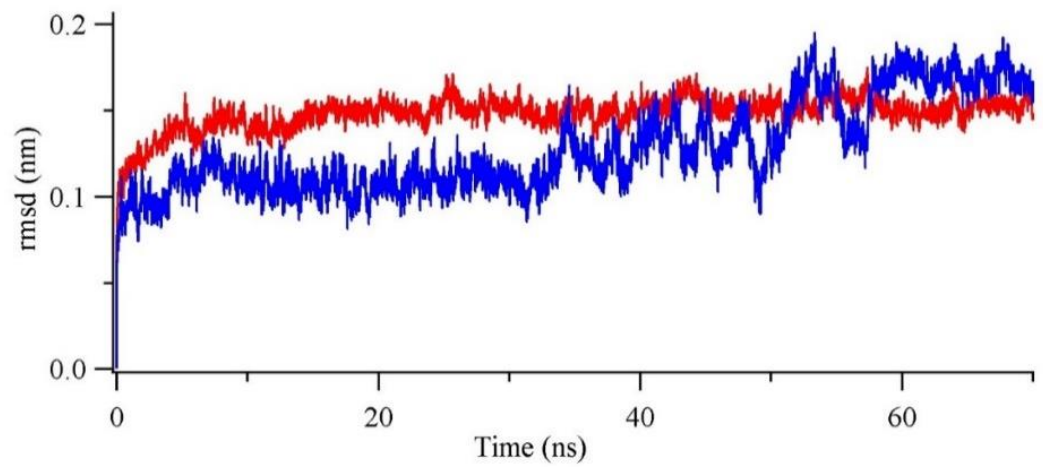

Fig. 1. The RMSD of Calpha atoms in liganded (blue) and unliganded (red) VP1 protein. The unliganded values are steadier and less fluctuated.

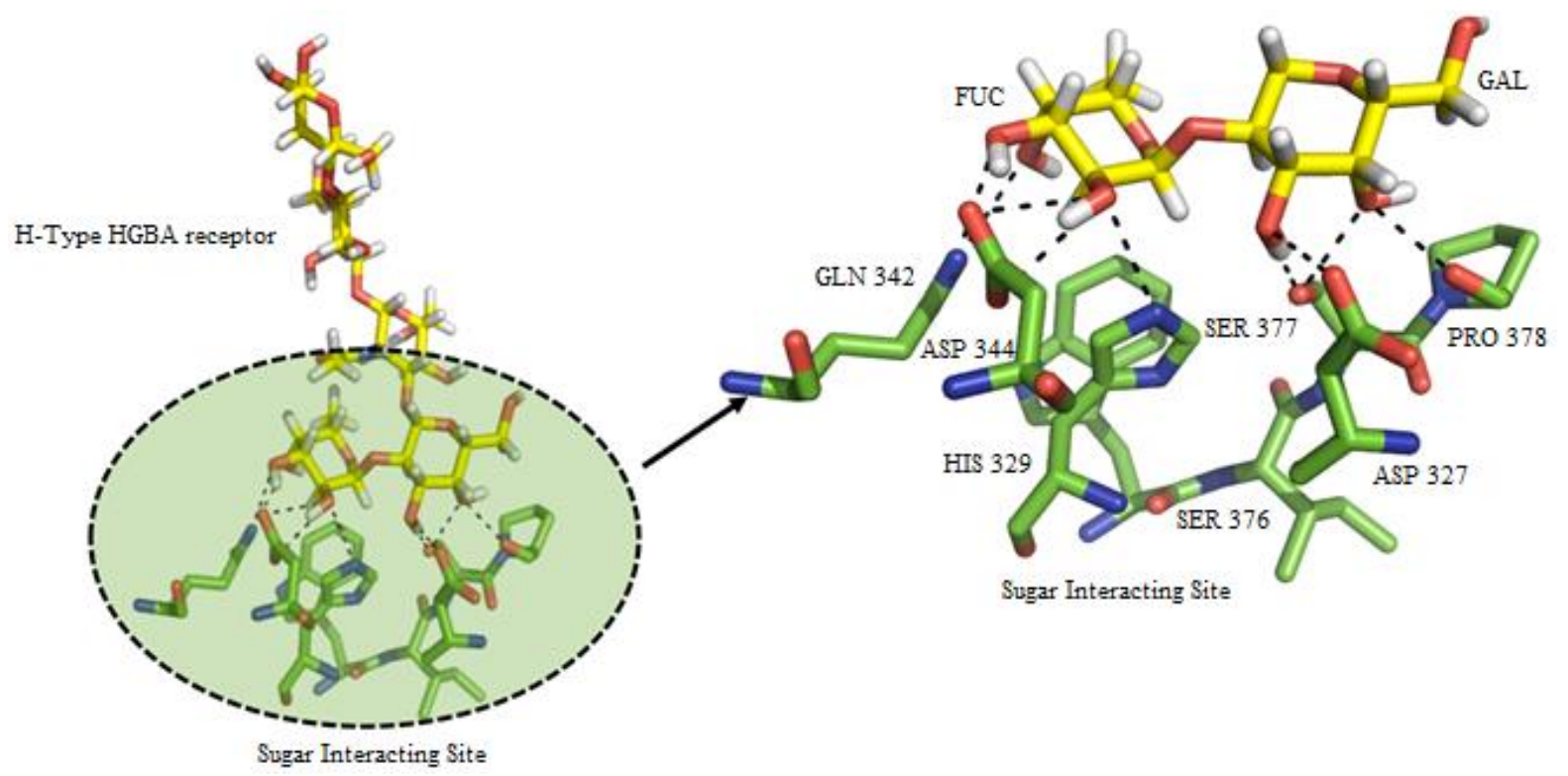

Fig. 2. Interacting pairs with residues labeled in the complex interface. The residues Gln342, Asp344, His 329 interact with $\alpha$-fucose and Ser377, Asp327, Pro378 and Trp375 with $\beta$-Galactose of the ligand.

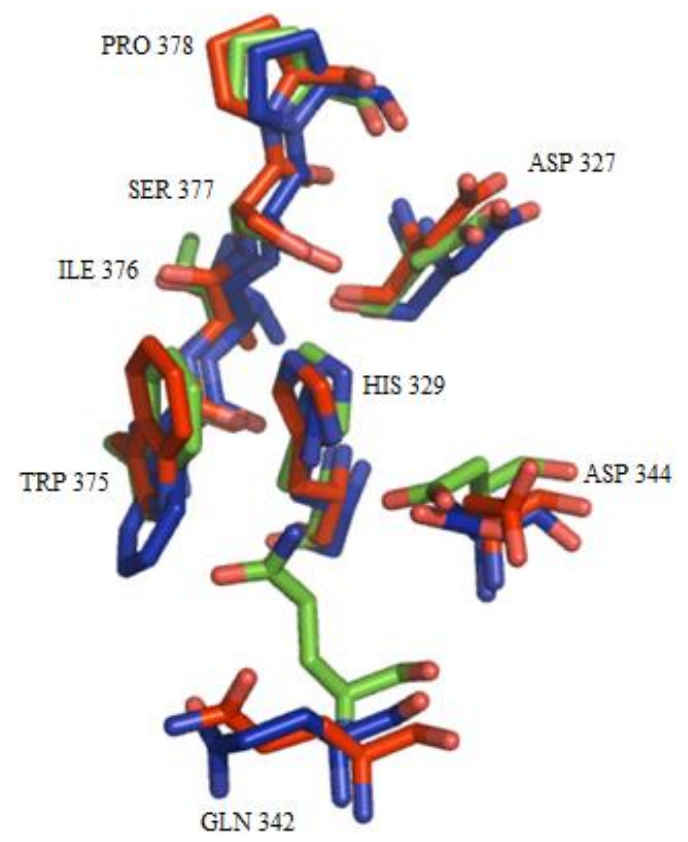

Fig. 3. Superimposed residues in the binding region for x-ray crystal structure (green) along with the most populated MD clusters of liganded (blue) and unliganded (red) VP1. 
The distances among proximal residues in the interaction region and fluctuations of these residues showed no significant changes upon ligand binding. This impose the fact that the presence of some other dynamic entities is involved in the variations of the RMSD values of VP1 upon sugar binding. Fig. 4a-f shows some of the change of the selected pair distances among the residues in the interaction region throughout MD simulations. Almost all the distances monitored showed similar pattern of a steady H-bonding interaction with $<3.5 \AA$. There is only one exception to this on the pairs of 3270D2-3800G where the distance in unliganded VP1 is too large for H-bonding (Fig. 4b).

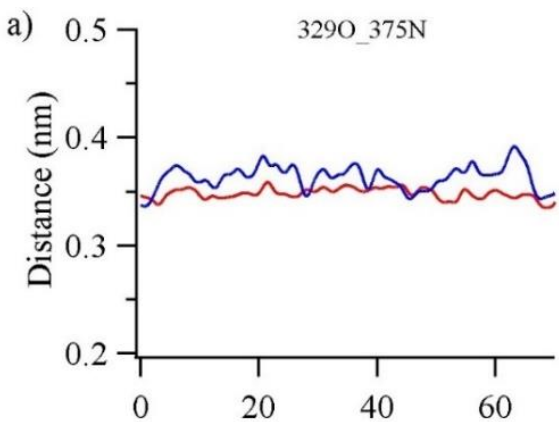

c)

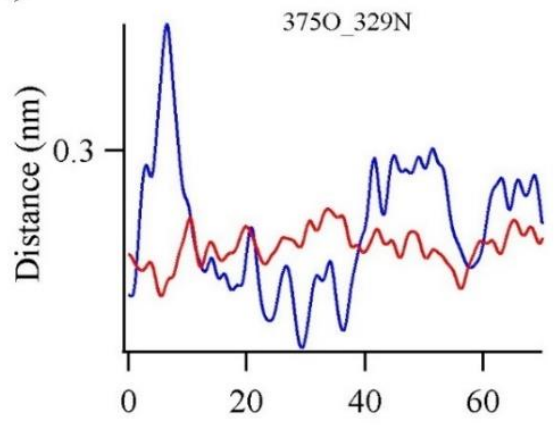

e)

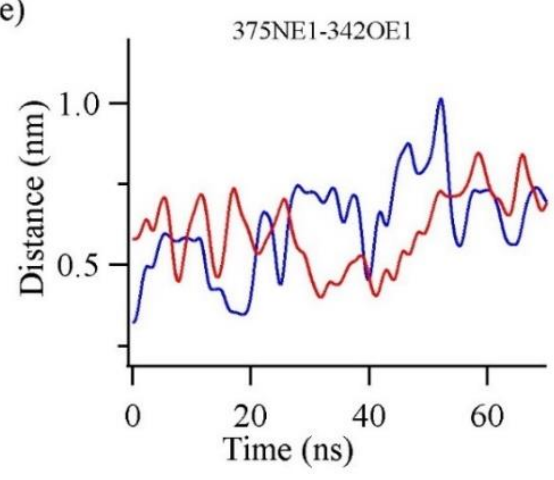

Unliganded
Not only the distances among the pairs in the interaction region, the fluctuations of those residues also showed no significant changes upon pentasaccharide binding (Fig. 5). On the other hand, the RMSF of the residues in the 395-405 region showed dramatic change upon binding. This is interesting given the fact that the ligand binding site is quite away from these residues. This cannot be simply explained by random loop motions.

The covariance analysis (also called principal component analysis, PCA) is a useful tool for investigating correlated dynamic movements in macromolecules.

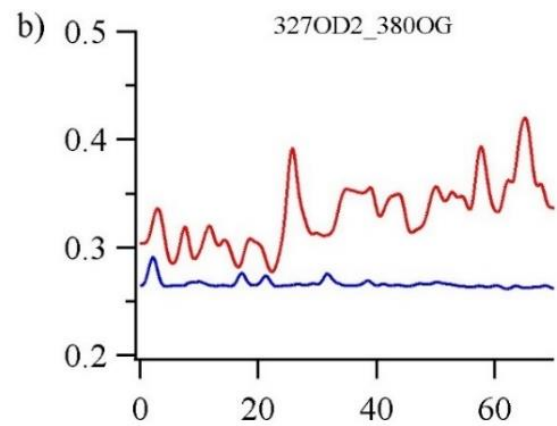

d)

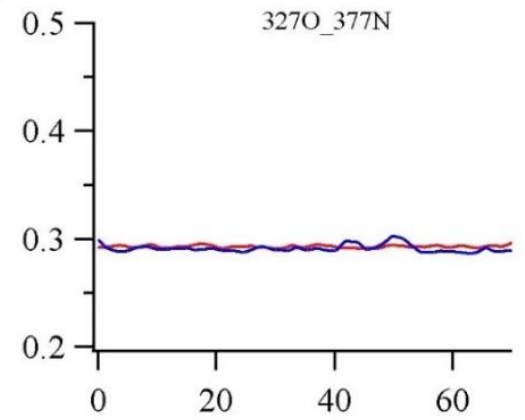

f)

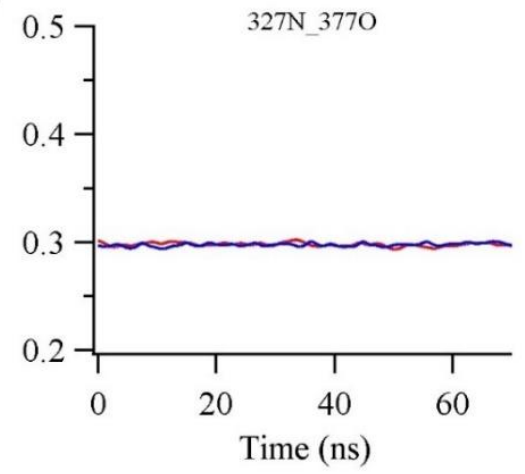

Liganded

Fig. 4. Critical distances among residues in the sugar binding site for liganded (blue) and unliganded (red) VP1 protein. The notation in distance is as follows: the first 3 digits show the residue number, rest shows the atom name in that residue (e.g, $375 \mathrm{NE} 1$ refers to $\mathrm{N} \varepsilon 1$ atom of $375^{\text {th }}$ residue). All data were smoothed using a Gaussian smoothing function of 10k fold. 


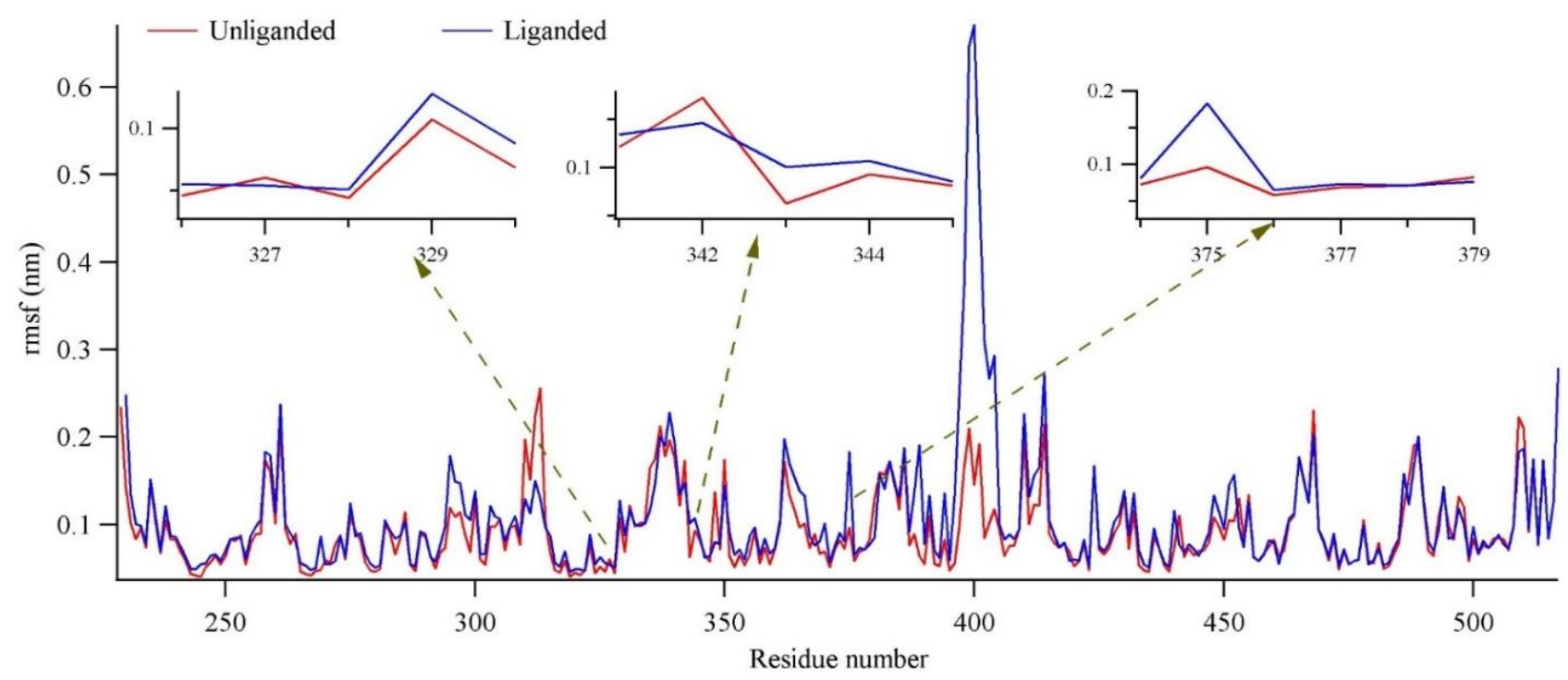

Fig. 5. The RMSF of liganded (blue) and unliganded (red) VP1 residues. The insets are the zoomed of the residues in the sugar binding site. Data show no noticeable rmsf difference at the binding site. The dashed arrows are not part of the data and only meant to show the location of zoomed insets (sugar binding site).

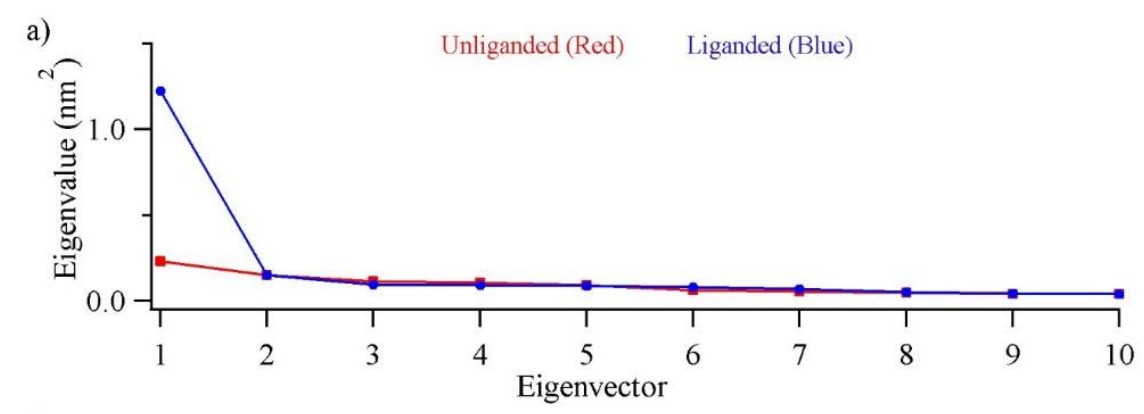

b)
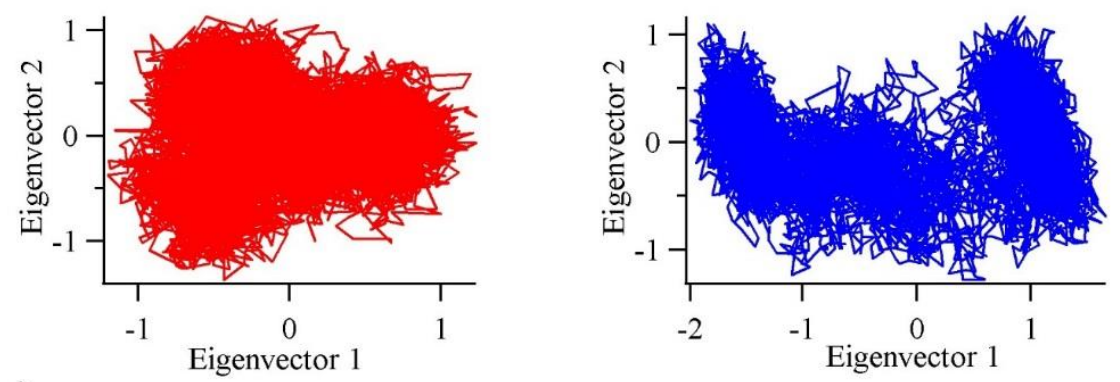

c)

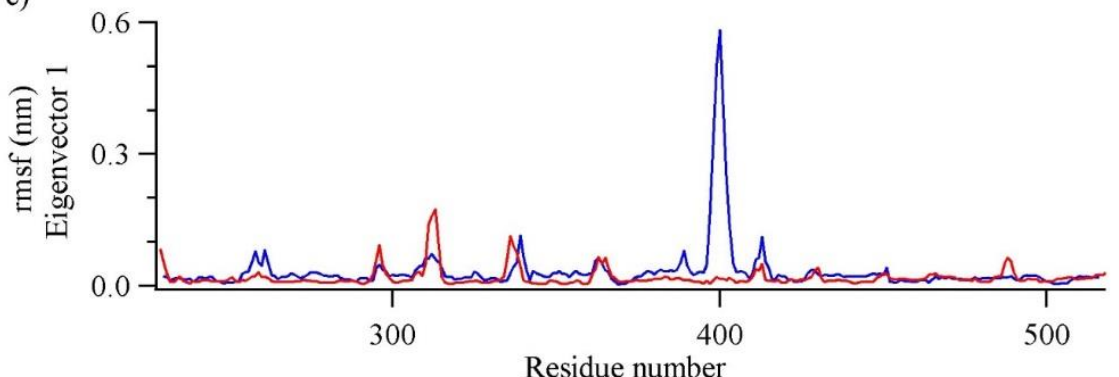

Fig. 6. Principal component analysis of unliganded (red) and liganded (blue) proteins for correlated motions. a) The first 10 eigenvalues showing two proteins differ in only eigenvector 1. b) The 2D projection of the trajectories on the first two eigenvectors (the most dominant collective motions) and c) RMSF of residues involved in the most dominant collective motion (eigenvector 1). 

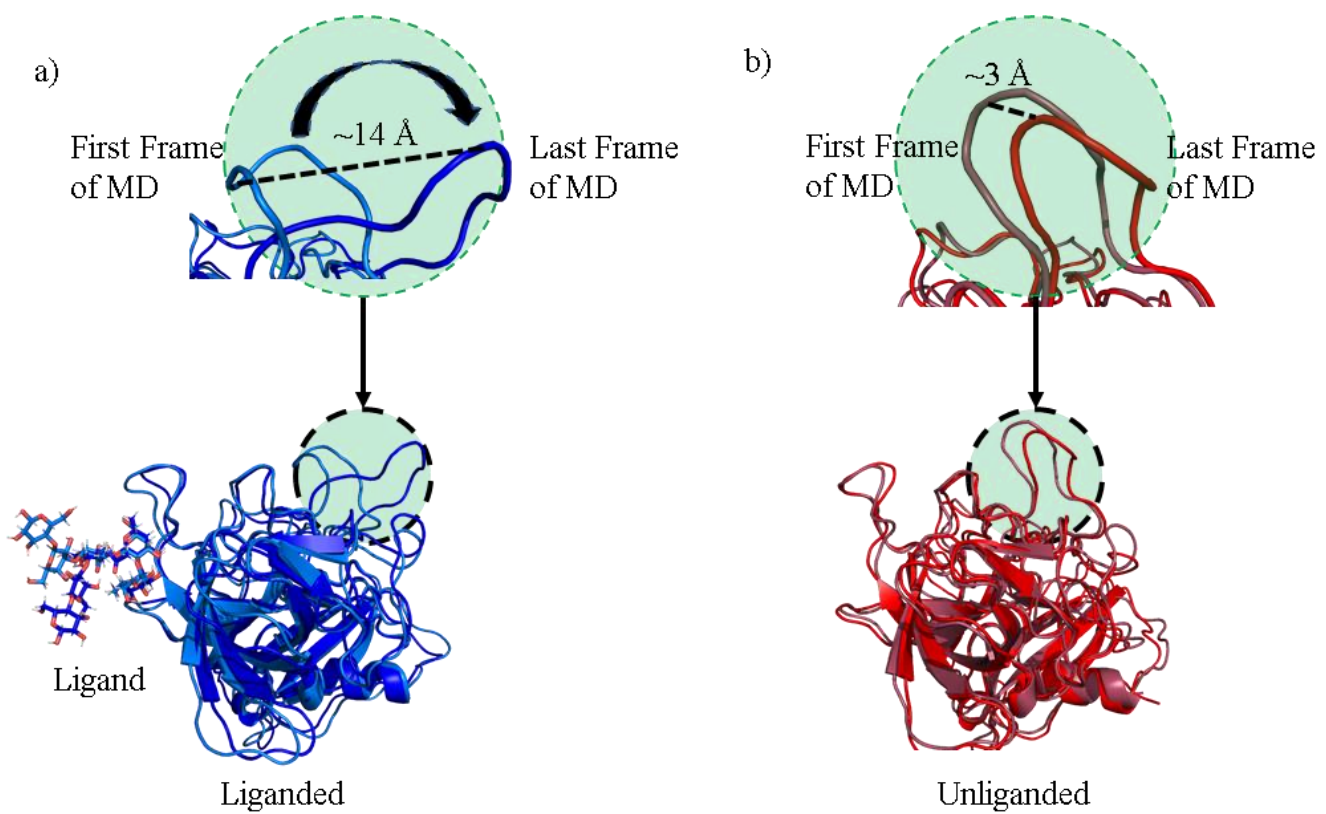

Fig. 7. The significant loop motion upon ligand binding is evident in the comparison of the first and last frame of MD simulations belong to liganded and unliganded structures.

Eigenvectors sorted by descending eigenvalues from a covariance matrix provide the essential collective motions. Therefore, the first eigenvector with the greatest eigenvalue shows the most dominant correlated motion.

Thus, we further dissected changes in the collective motion of VP1 by means of PCA. The first eigenvector for liganded spans over $1 \mathrm{~nm}^{2}$ space whereas it is only $0.25 \mathrm{~nm}^{2}$ for unliganded structure (Fig. 6a). The rest of the eigenvectors follow the same trend with the same values. The two-dimensional (2D) projection of the first two eigenvectors is very compact and mostly centers around a single cluster for unliganded while it is distributed (less-compact) and another distinct cluster starts to appear for the liganded structure (Fig. 6b). The RMSF value corresponding to the eigenvector 1 shows drastic changes in the 395-405 region of VP1 upon ligand binding (Fig. 6c). The overall analysis clearly shows that a significant motion become more visible and dominant upon ligand binding in VP1 protein structure. Since this motion is very far from the binding region, an allosteric effect might be involved in ligand binding mechanism. However, this needs to be validated by further experimental studies.

We also explored the structural changes that is suggested by covariance analysis with superimposing the last and first frames of MD simulation for both liganded and unliganded VP1. We have found that the ligand binding triggers a substantial mobility in the 395-405 loop that is distant to sugar binding site. The loop moves by 14 $\AA$ in liganded VP1(Fig. 7a) while it moves only $3 \AA$ in unliganded VP1, (Fig. 7. The significant loop motion upon ligand binding is evident in the comparison of the first and last frame of MD simulations belong to liganded and unliganded structures. The significant loop motion upon ligand binding is evident in the comparison of the first and last frame of MD simulations belong to liganded and unliganded structures over the course of MD simulations. This motion is not random as the repetitive MD simulations showed the same loop movements. The drastic motion of the loop upon ligand binding is clearly visible in compared representative structures of the first and last frame of MD simulations for liganded and unliganded structures. This data may be an indication of a cross talk between the sugar binding site and this loop which suggests an allosteric effect.

\section{Conclusion}

In this study, we investigated the dynamic changes occurred on the structure of wild type VP1 capsid protein upon binding to an H-type 1 HBGA antigen by means of molecular dynamic simulations. The data suggested very little dynamic changes in the binding region. This is in complete agreement with the experimental studies which showed the weak binding nature of the sugar. Data also showed a very interesting loop movement at a distal location from the ligand binding region, suggesting an allosteric communication between sugar binding site and this loop. Further experimental tests would be complementary and confirmative to this study. In addition to the experimental studies, molecular dynamics simulations could be extended to the interaction between VP1 and other antigen receptors such as A-type HBGA.

\section{Acknowledgement}

The numerical calculations reported in this paper were partially performed at TUBITAK ULAKBIM, High Performance and Grid Computing Center (TRUBA resources). This research did not receive any specific grant from funding agencies in the public, commercial, or not-for-profit sectors. 


\section{References}

1. Abraham, M.J., Murtola, T., Schulz, R., Páll, S., Smith, J.C., Hess, B. \& Lindahl, E. 2015. GROMACS: High performance molecular simulations through multi-level parallelism from laptops to supercomputers. SoftwareX, 12: 19-25. https://doi.org/10.1016/j.softx.2015.06.001

2. Aliabadi, N., Lopman, B.A., Parashar, U.D. \& Hall, A.J. 2015. Progress toward norovirus vaccines: considerations for further development and implementation in potential target populations. Expert Review of Vaccines, 14(9): 12411253. https://doi.org/10.1586/14760584.2015.1073110

3. Belliot, G., Lopman, B.A., Ambert-Balay, K. \& Pothier, P. 2014. The burden of norovirus gastroenteritis: an important foodborne and healthcare-related infection. Clinical Microbiology and Infection, 20(8): 724-730. https://doi.org/10.1111/1469-0691.12722

4. Caddy, S., Breiman, A., le Pendu, J. \& Goodfellow, I. 2014. Genogroup IV and VI canine noroviruses interact with histo-blood group antigens. Journal of Virology, 88(18): 10377-10391. https://doi.org/10.1128/JVI.01008-14

5. Choi, J.-M., Hutson, A.M., Estes, M.K. \& Prasad, B.V.V. 2008. Atomic resolution structural characterization of recognition of histo-blood group antigens by Norwalk virus. Proceedings of the National Academy of Sciences, 105(27):

https://doi.org/10.1073/pnas.0803275105

9175-9180.

6. de Graaf, M., van Beek, J., \& Koopmans, M.P. 2016. Human norovirus transmission and evolution in a changing world. Nature Reviews: Microbiology, 14(7): 421-433. https://doi.org/10.1038/nrmicro.2016.48

7. Garaicoechea, L., Aguilar, A., Parra, G.I., Bok, M., Sosnovtsev, S.V., Canziani, G., Green, K.Y., Bok, K. \& Parreno, V. 2015. Llama nanoantibodies with therapeutic potential against human norovirus diarrhea. PLoS One, 10(8): $\mathrm{e} 0133665$. https://doi.org/10.1371/journal.pone.0133665

8. Hoa Tran, T.N., Trainor, E., Nakagomi, T., Cunliffe, N.A. \& Nakagomi, O. 2013. Molecular epidemiology of noroviruses associated with acute sporadic gastroenteritis in children: global distribution of genogroups, genotypes and GII.4 variants. Journal of Clinical Virology, 56(3): 185-193. https://doi.org/10.1016/j.jcv.2012.11.011

9. Ishida, T. 2018. Computational analysis of carbohydrate recognition based on hybrid QM/MM modeling: a case study of norovirus capsid protein in complex with Lewis antigen. Physical Chemistry Chemical Physics, 20(7): 4652-4665. https://doi.org/10.1039/C7CP07701G

10. Kambhampati, A., Koopmans, M. \& Lopman, B.A. 2015. Burden of norovirus in healthcare facilities and strategies for outbreak control. Journal of Hospital Infection, 89(4): 296-301. https://doi.org/10.1016/j.jhin.2015.01.011

11. Karst, S.M., Wobus, C.E., Goodfellow, I.G., Green, K.Y. \& Virgin, H.W. 2014. Advances in norovirus biology. Cell Host Microbe, 15(6): 668-680. https://doi.org/ 10.1016/j.chom.2014.05.015

12. Kocak, A., Erol, I., Yildiz, M. \& Can, H. 2016. Computational insights into the protonation states of catalytic dyad in BACE1-acyl guanidine based inhibitor complex. Journal of Molecular Graphics and Modeling, 70: 226-235. https://doi.org/10.1016/j.jmgm.2016.10.013

13. Kocak, A. \& Yildiz, M. 2017. Docking, molecular dynamics and free energy studies on aspartoacylase mutations involved in Canavan disease. Journal of Molecular Graphics and Modeling, 74: 44-53. https://doi.org/ 10.1016/j.jmgm.2017.03.011

14. Kotloff, K.L., Nataro, J.P., Blackwelder, W.C., Nasrin, D., Farag, T.H., Panchalingam, S., Wu, Y., Sow, S.O., Sur, D., Breiman, R.F., Faruque, A.S., Zaidi, A.K., Saha, D., Alonso, P.L., Tamboura, B., Sanogo, D., Onwuchekwa, U., Manna, B., Ramamurthy, T., Kanungo, S., Ochieng, J.B., Omore, R., Oundo, J.O., Hossain, A., Das, S.K., Ahmed, S., Qureshi, S., Quadri, F., Adegbola, R.A., Antonio, M., Hossain, M.J., Akinsola, A., Mandomando, I., Nhampossa, T., Acacio, S., Biswas, K., O'Reilly, C.E., Mintz, E.D., Berkeley, L.Y., Muhsen, K., Sommerfelt, H., RobinsBrowne, R.M. \& Levine, M.M. 2013. Burden and aetiology of diarrhoeal disease in infants and young children in developing countries (the Global Enteric Multicenter Study, GEMS): a prospective, case-control study. Lancet, 382(9888): 209-222. https://doi.org/10.1016/S01406736(13)60844-2

15. Kubota, T., Kumagai, A., Ito, H., Furukawa, S., Someya, Y., Takeda, N., Ishii, K., Wakita, T., Narimatsu, H. \& Shirato, H. 2012. Structural basis for the recognition of Lewis antigens by genogroup I norovirus. Journal of Virology, 86(20): 11138-11150. https://doi.org/10.1128/JVI.00278-12

16. Lindorff-Larsen, K., Piana, S., Palmo, K., Maragakis, P., Klepeis, J.L., Dror, R.O. \& Shaw, D.E. 2010. Improved side-chain torsion potentials for the Amber ff99SB protein force field. Proteins, 78(8): 1950-1958. https://doi.org/10.1002/prot.22711

17. Lochridge, V.P., Jutila, K.L., Graff, J.W. \& Hardy, M.E. 2005. Epitopes in the P2 domain of norovirus VP1 recognized by monoclonal antibodies that block cell interactions. Journal of General Virology, 86(Pt 10): 27992806. https://doi.org/10.1099/vir.0.81134-0

18. Olsson, M.H., Sondergaard, C.R., Rostkowski, M. \& Jensen, J.H. 2011. PROPKA3: Consistent Treatment of Internal and Surface Residues in Empirical pKa Predictions. Journal of Chemical Theory and Computation, 7(2): 525-537. https://doi.org/10.1021/ct100578z

19. Patel, M.M., Hall, A.J., Vinje, J. \& Parashar, U.D. 2009. Noroviruses: a comprehensive review. Journal of Clinical Virology, 44(1): 1-8. https://doi.org/10.1016/j.jcv.2008.10.009

20. Rocha-Pereira, J., Neyts, J. \& Jochmans, D. 2014. Norovirus: targets and tools in antiviral drug discovery. Biochemical Pharmacology, 91(1): 1-11. https://doi.org/10.1016/j.bcp.2014.05.021

21. Sapparapu, G., Czako, R., Alvarado, G., Shanker, S., Prasad, B.V., Atmar, R.L., Estes, M.K. \& Crowe, J.E., Jr. 2016. Frequent Use of the IgA Isotype in Human B Cells Encoding Potent Norovirus-Specific Monoclonal Antibodies That Block HBGA Binding. PLoS Pathog, 12(6): https://doi.org/10.1371/journal.ppat.1005719 
22. Schrödinger, L. 2015. Maestro. New York, NY: Schrödinger, LLC.

23. Shanker, S., Czako, R., Sankaran, B., Atmar, R.L., Estes, M.K. \& Prasad, B.V. 2014. Structural analysis of determinants of histo-blood group antigen binding specificity in genogroup I noroviruses. Journal of Virology, 88(11): 6168-6180. https://doi.org/10.1128/JVI.00201-14

24. Tamminen, K., Malm, M., Vesikari, T. \& Blazevic, V. 2016. Mucosal Antibodies Induced by Intranasal but Not Intramuscular Immunization Block Norovirus GII.4 VirusLike Particle Receptor Binding. Viral Immunology, 29(5): 315-319. https://doi.org/10.1089/vim.2015.0141

25. Tan, M. \& Jiang, X. 2014. Vaccine against norovirus. Hum Vaccin Immunother, 10(6): 1449-1456. https://doi.org/ $10.4161 /$ hv. 28626
26. Toukan, K. \& Rahman, A. 1985. Molecular-dynamics study of atomic motions in water. Physical Review B: Condensed Matter and Materials Physics, 31(5): 26432648.

27. Wang, J., Wolf, R.M., Caldwell, J.W., Kollman, P.A. \& Case, D.A. 2004. Development and testing of a general amber force field. Journal of Computational Chemistry, 25(9): 1157-1174. https://doi.org/10.1002/jcc.20035

28. Wang, J., Wang, W., Kollman, P.A. \& Case, D.A. 2006. Automatic atom type and bond type perception in molecular mechanical calculations. Journal of Molecular Graphics and Modelling, 25(2): 247-260. doi: https://doi.org/10.1016/j.jmgm.2005.12.005

29. White, P.A. 2014. Evolution of norovirus. Clinical Microbiology and Infection, 20(8): 741-745. https://doi.org/10.1111/1469-0691.12746 